\title{
EFFECT OF ACQUISITION TYPE ON INDUSTRIAL DEVELOPMENT IN EMERGING MARKETS: EVIDENCE FROM CHINA
}

\author{
Qi YUE ${ }^{1}$, Ping DENG ${ }^{2}$, Xing HUA ${ }^{3}$, Luan JIANG ${ }^{1}$ \\ ${ }^{1}$ School of Economics and Management, South China Normal University, Guangzhou, China \\ ${ }^{2}$ Monte Ahuja College of Business, Cleveland State University, Cleveland, Ohio, USA \\ ${ }^{3}$ Department of Finance and Economics, Guangdong Youth Vocational College, \\ Guangzhou, China
}

Received 10 August 2020; accepted 12 August 2021

\begin{abstract}
In this paper, we proposed a model of how corporate acquisition influences industrial performance by exploring industry-level and firm-level ownership characteristics in emerging markets. Based on a database of 1,934 acquisitions of listed firms in China, we examined the relationship between corporate acquisition type and industrial performance and the moderating effects of industrial and firm ownership characteristics. The study generated three major findings: 1) compared with cross-industry acquisitions, intra-industry acquisitions of firms have a stronger positive effect on industrial performance; 2) corporate ownership and industrial ownership variables exert different moderating impact on the relationship between acquisition type and industrial performance; and 3) firm ownership and industrial ownership have a joint moderating effect on the relationship between acquisition type and industrial performance. By conceptually arguing and empirically verifying how multi-level factors influence industrial performance in the context of emerging economies, we contributed to the study of the relationship between the micro-level firm acquisition and the macro-level industrial development in several distinct ways.
\end{abstract}

Keywords: acquisition type and performance, cross-industry and intra-industry acquisitions, Chinese companies, emerging markets, ownership characteristics, state-owned enterprises (SOEs).

JEL Classification: L20, L25, M16, M21.

\section{Introduction}

Given their vitally strategic importance for the growth of firms and industries, acquisitions have increasingly become a widespread research theme at various levels and across fields particularly in emerging economies (Deng, 2013; Gaur et al., 2013; Park, 2003; Zaremba et al., 2018). As two distinct types of acquisitions, intra-industry acquisitions are conducted in the

*Corresponding author. E-mail: p.deng@csuohio.edu

Copyright (c) 2022 The Author(s). Published by Vilnius Gediminas Technical University

This is an Open Access article distributed under the terms of the Creative Commons Attribution License (http://creativecommons. org/licenses/by/4.0/), which permits unrestricted use, distribution, and reproduction in any medium, provided the original author and source are credited. 
same industry, whereas cross-industry acquisitions occur in different industries (Cai \& Tian, 2019; Lin et al., 2018; Wu \& Deng, 2020). Through intra-industry acquisitions, firms can rapidly acquire complementary resources and capabilities, achieve economy of scale, and lead to scope economy effects (Deng \& Yang, 2015; Gaur et al., 2013). Through crossindustry acquisitions, companies can obtain more market entry opportunities, get into a new business more quickly, share risks, and get potential synergies (Lin \& Chou, 2016; Zaremba et al., 2018). With a rapid economic growth in China, corporate acquisitions of Chinese firms show obvious characteristics of high frequency, large scale, and massive quantity domestically and internationally (Cai \& Tian, 2019; Deng \& Yang, 2015). Recently, a number of Chinese companies conducted notable cross-border acquisitions; they involve both intra-industry acquisitions (e.g., Geely's acquisition of Volvo and Haier's acquisition of GE's home appliance business) and cross-industry acquisitions (e.g., Midea's acquisition of Kuka in Germany) (Cai \& Tian, 2019; Lin et al., 2018; Wu \& Deng, 2020).

However, researchers in this important research stream also found that different types of acquisitions have different effects and outcomes (Capron, 1999; Capron \& Pistre, 2002; Cornaggia \& Li, 2019). Some researchers (e.g., Chakrabart \& Mitchell, 2016) found that the benefit of intra-industry acquisition is higher than that of cross-industry acquisition. However, the high degree of relatedness between the two parties of an intra-industry acquisition can also have a certain negative effect (Tan \& Sousa, 2018), and intra-industry acquisition may only reduce the financial risk, but not necessarily bring significant benefits (Bergh, 1997; Park, 2003). In addition, meta-analyzes of post-acquisition performance (e.g., King et al., 2004) indicate that the relatedness of an acquisition could not explain the change of acquisition performance.

It can be seen that different types of acquisitions on industry performance in existing studies are controversial (Graebner et al., 2017; Erel et al., 2015). One important reason could be that prior studies consider acquisition outcome simply from the firm level rather than from cross-level research (Bettinazzi \& Zollo, 2017). However, acquisition actions of individual firms at different levels can lead to notable differences of acquisition outcome (Bertrand \& Capron, 2015; Yan et al., 2018). As there is a lack of cross-level research, the first objective of our study is to analyze the impact of different types of acquisitions (i.e., intra-industry and cross-industry acquisitions) on industrial performance. In doing so, we endeavor to clarify conflicting empirical findings in the existing literature.

In emerging markets, another important reason that acquisition types have different performance effects is that the institutional context of enterprises is dramatically different (Deng et al., 2020; Peng et al., 2008; Yue et al., 2021). Ownership is one of the key elements that influence institutional context (Li et al., 2019; Humphery-Jenner et al., 2017). For corporate acquisition decisions, there are two important dimensions of ownership factors. One is the ownership structure of a firm, which indicates whether the firm is state-owned or not, while the other is the ownership structure of the industry where the enterprise is located (Li et al., 2019; Humphery-Jenner et al., 2017). In China, state-owned enterprises (SOEs) play a vital role in the development of all major industrial sectors and especially in the process of industrial transformation and upgrading based on acquisitions and reorganizations of firms (Li \& Wan, 2016; Xin et al., 2019; Yan et al., 2018). Meanwhile, the 
proportion of SOEs varies substantially in different industries (Chen, 2008; Deng, 2013; Xin et al., 2019). From the structure-conduct-performance (SCP) perspective, market behavior and performance would also be affected by the ownership structure characteristics of an industry (Meuer, 2014). However, there are limited studies on how ownership-related factors influence corporate acquisition on industry performance (Graebner et al., 2017; Yan et al., 2018; Zaremba et al., 2018). Hence, the second objective of our study is to analyze moderating effects of ownership-related attributes on the relationship between acquisition type and industrial performance.

On the basis of a database of 1,934 acquisitions of listed Chinese firms, we examined the relationship between acquisition type and industrial performance and the moderating effects of industrial and firm ownership variables and generated three major findings. First, compared with cross-industry acquisitions, intra-industry acquisitions of firms have a stronger positive effect on industrial performance. Second, corporate ownership and industrial ownership attributes exert different moderating effects on the relationship between acquisition type and industrial performance. Third, firm- and industry-level ownerships have a joint moderating effect on the relationship between acquisition type and industrial performance.

As such, our research aims to make three contributions. First, it is a cross-level study on the role of acquisition type. In previous studies, the difference of acquisition type and its functions are discussed mainly from the same level, such as the impact of corporate acquisition types on performance of firms, or industry acquisition types on industry performance. By analyzing the influence of acquisition type (a micro-level factor) on industrial performance (a macro-level outcome), our cross-level study is badly needed in the existing literature. Second, ownership is an important factor that affects institutional environment of firms, but existing research has not yet analyzed its role on acquisition type in particular. From the ownership angel, we contend that the performance difference of acquisition type on industrial performance will be affected by both firm-level and industry-level ownership factors. Third, based on the interaction effects of both firm- and industry-level factors, we argue and verify the joint moderating effect of the two ownership factors at two different levels.

Overall, this research enriches the ownership theory and institutional theory on the acquisition behaviors of firms and industrial performance in the context of emerging markets. In addition, our study has also generated several managerial and policy implications. For business practitioners, our findings may help them to better leverage different types of acquisition activities and promote the optimization of industrial structure, thus enhancing their competitive advantage. For policy makers, this research may enable them to enhance the policy efficiency of industrial structure transformation and upgrading by better regulating different types of corporate acquisitions.

The structure of the paper is as follows. Section 1 summarizes prior research and describes hypotheses. In section 2, we explain methodology of the paper in terms of sample, measures, and the regression models, while in section 3 we report and interpret the empirical results. In section 4, we discuss the research particularly with regard to its contributions, practical implications, and limitations. We conclude our research in the last section. 


\section{Literature review and hypothesis development}

\subsection{Firm acquisition type and industrial performance}

Based on the industries where the two parties are involved, acquisitions can be divided into intra-industry acquisitions and cross-industry acquisitions (Bergh, 1997; Meuer, 2014; Park, 2003). There have been a variety of research results on the relationship between acquisition type and firm performance at the firm level from different angels. For intra-industry acquisition, from the perspective of resources, acquisition can exert more scale effect; from the transaction cost perspective, acquisition can reduce the opportunist risks in acquisition and integration; from the innovation perspective, it is conducive to complementarity, learning and innovation (Tehseen et al., 2021); and from the perspective of institutional theory, intra-industry acquisition has higher legitimacy and is conducive to integration after the acquisition (Graebner et al., 2017; King et al., 2004; Vega Martinez et al., 2020). In all across-border acquisition transactions, intra-industry acquisitions accounted for the majority of acquisitions (Cornaggia \& Li, 2019; Harris \& Ravenscraft, 1991; Humphrey-Jenner et al., 2017). Empirical studies have found that related acquisitions improve the business performance of firms, while diversified acquisitions may not help or even damage the business performance (Graebner et al., 2017; Xin et al., 2019; Yue et al., 2021). Park (2003) found that intra-industry acquisition is more profitable than cross-industry acquisition for those acquisitions with assets exceeding US\$10 million from 1974 to 1979 , which is especially true if the performance measurement is based on accounting. Based on investigating the impact of industry correlation between acquiring parties and target firms, Bettinazzi and Zollo (2017) found that the higher the correlation between the two firms, the more positive impact on acquisition performance.

Meanwhile, some studies have pointed out that intra-industry acquisition does not always bring benefits to enterprises. For example, the case study of Marcela, DiVito, and Desy (2016) and the empirical study of Orsi, Ganzaroli, De Noni, and Marelli (2015) based on 218 acquisition samples found that intra-industry acquisition is very likely to destroy innovation potential due to knowledge redundancy and technology redundancy, which in turn has negative influence on acquisition performance. Such value destroying results associated with intra-industry acquisitions were similarly found by other researchers. Karim (2006) and Sears and Hoetker (2014) confirmed that the knowledge redundancy caused by the acquisition of enterprises in the same industry and the contradiction and conflict between the employees of both sides for the purpose of competing for limited resources could lead to the negative impact of acquisition value.

However, compared to the intra-industry acquisition, the effect of cross-industry acquisition on firms tends to be more controversial (Cai \& Tian, 2019; Graebner et al., 2017). On the one hand, cross-industry acquisition can enable firms to obtain more resources, expand their scale and increase their market influence. In particular, through cross-industry acquisition, firms can enter new markets and realize diversified expansion strategies more quickly. For example, by examining 8,674 enterprises from 1982 to 1997, Ahn et al. (2006) found that diversified acquisitions dispersed business risks, thus making it possible for firms to deal with crisis successfully. Based on 96 high-tech firms completed in the pharmaceutical, 
chemical and electronic industries in 1996, Makri, Hitt and Lane (2010) found that when cross-industry acquisition was carried out, exploratory learning was enhanced which in turn contributed to the quality and novelty of invention, thus improving the economic value of acquisition. However, the biggest challenge is that cross-industry acquisition is increasingly harder to achieve synergy and resource integration (Graebner et al., 2017). For instance, Yin and Shanley (2008) found that unrelated acquisitions increase the challenges of postacquisition integration. Based on the study of 3, 604 acquisitions in 1994-2006, Furfine and Rosen (2011) found that cross-industry acquisition brought significantly more risks than the intra-industry acquisition. Additionally, unrelated and diversified acquisitions of SOEs are usually the result of government intervention, which is not conducive to the improvement of firm performance (Yue et al., 2021; Zaremba et al., 2018).

Some scholars have also discussed the possible effects of firm acquisition on industry. Acquisition in advantageous firms promotes industrial development (Gaur et al., 2013), strengthens the market competitiveness of the industry (Bettinazzi \& Zollo, 2017), and realizes the economy of industrial concentration to advantageous firms and industrial spatial distributions (Brito, 2003). Firms can also follow the market demand and realize the improvement of industrial resource allocation efficiency (Garcia-Castro \& Francoeur, 2016; Capron \& Pistre, 2002), and surplus industries are weakened in acquisitions and demand industries grow rapidly (Bertrand \& Capron, 2015). However, the existing research has not fully explored the impact of different types of firm acquisitions on industrial performance particularly from cross-level angels. This study endeavors to investigate the differences between cross-industry acquisition and intra-industry acquisition and their impact on industrial performance from three perspectives.

First of all, from the perspective of overall synergy, we contend that the "synergy effect" of intra-industry acquisition will be stronger (Cuypers et al., 2017; Hitt et al., 1996). Compared with cross-industry acquisition, through intra-industry acquisition, the distinctive management ability in the industry can be transferred to the target firm, which may lead to an obvious scale effect if the industries of both parties are highly related each other (Park, 2003; Bettinazzi \& Zollo, 2017; Capron \& Pistre, 2002). Such synergy effect is conducive to enhancing the overall integration effect in the post- acquisition (Gaur et al., 2013), thereby improving the performance of both parties involved and thus contributing to the industrial performance as a whole.

Second, from the perspective of market structure, intra-industry acquisition tends to have a more favorable "structural effect" (Bertrand \& Capron, 2015). Under the condition of excessive competition in most industries of China, acquisition is likely to reduce the competitive pressure on the market and make products and services more valuable (Gaur et al., 2013). Accordingly, intra-industry acquisition is conducive to improving the market competition structure in the industry, which further promotes the development of the entire industry (Xin et al., 2019).

Third, from the perspective of resource theory, it is believed that intra-industry acquisition has a greater "integration effect" than cross-industry acquisition does (Vega Martinez et al., 2020). For cross-industry acquisitions, the original industry of the firm will inevitably be affected because resources are scattered into other industries. At the same time, the dif- 
ficulties and obstacles of cross-industry acquisition may cause the original business of the owner and the firm to be affected, which will have a potential negative impact on the industry as a whole (Erel et al., 2015; Furfine \& Rosen, 2011; Tian et al., 2018). In contrast, the two parties of intra-industry acquisitions will integrate and reconfigure their resources among firms to produce a greater integration effect without dispersing resources, thereby expecting to obtain abnormal acquisition returns (Capron \& Pistre, 2002; Sears \& Hoetker, 2014). Therefore, we propose our first hypothesis.

H1: Compared with cross-industry acquisitions, intra-industry acquisitions are more beneficial to industrial performance in China.

\subsection{Moderating effect of industrial ownership characteristics}

The characteristics of industrial ownership have an impact on industrial performance and are especially more significant in emerging markets (Chen et al., 2017). From the perspective of acquisition activities, the effect of industrial state-owned property on intra-industry acquisition in emerging markets should be positive. This is because the greater the industrial state-owned proportion is, the less competitive the industry is, resulting in lower uncertainty (Luo et al., 2010). From the view of intra-industry acquisitions, although small firms may be swallowed up by large ones or large firms may cooperate with each other, the main purpose is to reduce direct competition, improving the market position of dominant firms and expanding market share (Deng \& Zhang, 2018).

However, it is difficult to reduce the competitive strength of the industry through intraindustry acquisitions with relatively higher competitive strengths, for the industry with a small industrial state-owned proportion (Gaur et al., 2013). For China and other emerging countries, at an early stage of development, a stable competitive environment is relatively more conducive to the consolidation and construction of international competitiveness of advantageous firms, thus driving the overall development of the industry (Deng \& Zhang, 2018; Lin et al., 2018). For firm acquisition activities, in a relatively stable environment, intra-industry acquisition is more likely to have sufficient internal and external environmental conditions to support acquisition integration effect more effectively, thus promoting resource coordination and optimal allocation within the industry (Louis, 1980). In China, the industries with more state-owned ownership are more stable with less competition such as oil or steel industry (Lin et al., 2018). Intra-industry acquisition could increase the market concentration and lower the industry competition, which bring more stable condition and more time for the corporate integration after acquisition (Bettinazzi \& Zollo, 2017; Gaur et al., 2013).

In addition, if we look at cross-industry acquisitions with more state-owned ownership, due to the lack of competitive pressure in the industry, for firms under this background, especially those with a higher degree of government connections, cross-industry acquisitions are more likely to be based on external opportunity orientation rather than internal capability orientation (Palich et al., 2000). Therefore, cross-industry acquisitions could lead to the "diversification trap" and negatively affect the overall performance of their original industries (Palich et al., 2000). Gaur and his collaborators (2013) pointed out that in a regulated market 
such as China, the firm that achieves unrelated diversified development through acquisition is to some extent a "signal" of government regulation of industrial development. There are obvious "opportunity-oriented" or even "policy arbitrage" behaviors of firms in cross-industry acquisition in China, which is not conducive to the overall development of firms and the industry in the long term. As a consequence, we propose our second hypothesis, arguing the moderating effect of industrial state-owned ownership.

H2: The greater the proportion of state-owned shares in the industry, the more positive effect of intra-industry acquisition and more negative effect of cross-industry acquisition on industrial performance.

\subsection{Moderating effect of firm ownership characteristics}

In China, cross-industry acquisitions by state-owned enterprises (SOEs) are more likely to be driven by scale expansion or restructuring influenced by non-market factors (HumpheryJenner et al., 2017). Diversification and especially unrelated diversification may weaken their competitive position (Jovanovic \& Braguinsky, 2004). The negative effect of its acquisition and integration will indirectly affect the industry in which the firm was originally located. In particular, affected by policies, SOEs are more likely to implement "policy-oriented" cross-industry acquisitions and reduce their main business investment, thus affecting the development of the original industry. There are two main forms of policy-oriented crossindustry acquisition. One is passive, that is, being entrusted or arranged by the government to acquire and restructure firms in some other industries, especially those with poor performance (Furfine \& Rosen, 2011; Vega Martinez et al., 2020), which could be called "policy compulsory". The other is active, that is, because there is policy support in some industries, the cross-industry acquisition can quickly help an SOE enter into the industry supported by the government, thereby obtaining policy support and preferable government treatment (Deng, 2013; Luo et al., 2010). This can be called "policy inducted".

However, there are often two possible consequences of these two policy-oriented crossindustry acquisitions. One is to affect the development of the corporate main business, thus affecting the development of the industry where the main business is located. The other is the so-called "diversification trap", which leads to the plight of enterprises, thus negatively affecting the industry where they are located. Besides, in China, the intra-industry acquisition of SOEs is more likely to be based on their own development expansion, resource integration via acquisitions can enhance the industry competition structure conducive to their own development (Lin et al., 2018). As a result, cross-industry acquisitions for Chinese SOEs would have more negative effect while intra-industry acquisitions having more positive effect for industry development.

In addition, cross-industry acquisitions of non-SOEs or private firms are more likely to be related to diversified acquisitions. They have stronger strategic motives and long-term goals to promote the long-term innovation and sustainable development of firms, thus promoting the competitiveness improvement and innovation environment of their industries (Lins \& Servaes, 2002). Even if it is not related to the acquisition, non-SOEs are more likely to implement "policy arbitrage" acquisition (Blonigen, 2016). The main resources in the post- 
acquisition have not been invested in new businesses, but have obtained more policy support to promote the development of their original main businesses (Jo \& Kim, 2019). It is found that the main business proportion of non-SOEs increases after cross-industry acquisition in China (Cai \& Tian, 2019; Li \& Deng, 2017). In sum, compared with the SOEs, the crossindustry acquisition of non-SOEs has a relatively small potential negative impact on their industry despite a positive effect. Therefore, we propose our third hypothesis and contend the moderating effect of corporate ownership characteristics.

H3: When an acquiring firm is state-owned, there are more likely positive effect of intraindustry acquisition and negative effect of cross-industry acquisition.

\subsection{Joint moderating effect of industrial ownership and firm ownership}

In order to better reveal the influence of the ownership characteristics on the acquisition type and industrial performance, we further analyze how the firm-level ownership affects the moderation effect of the industrial ownership characteristics on the acquisition type and industrial performance. We analyze this joint moderating effect from two aspects.

On the one hand, the impact of industrial ownership structure on the positive role of intra-industry acquisition would be weakened in the acquisitions of SOEs but more prominently in the acquisitions of non-SOEs. Because the main impact of industrial ownership characteristics lies in the impact on competitive structure and industry dynamics (Furfine \& Rosen, 2011; Vega Martinez et al., 2020). In China, the high proportion of state-owned ownership in industry usually means that the competition is not intense, which can bring a stable environment for the whole process of acquisition, especially the integration and reorganization after acquisition. However, for SOEs, due to their institutional advantages, the resources for acquisition and post-acquisition integration would be more sufficient, and they can also obtain more stable policy guarantee and support (Chen et al., 2017; Deng \& Yang, 2015); hence, the potential positive role of the external stable environment is not so significant, and the impact of the industry ownership structure will be weakened. However, for non-SOEs, they need a relatively stable external environment due to the lack of sustained resource support (Wu \& Deng, 2020). When non-SOEs conduct strategic activities including acquisition, the high dynamic environment and competitive intensity may lead to the inability of enterprises to allocate resources according to the original plan (Chen et al., 2017). A relatively stable environment can avoid the impact of such external dynamic on the resources and time required in the acquisition and integration process, obtaining better acquisition integration performance and promoting the development of the industry (Meyer-Doyle et al., 2019; Tian et al., 2018). Therefore, in industries with a high proportion of state-owned ownership, the benefits of intra-industry acquisition by non-SOEs will be greater.

On the other hand, the negative effect of industrial ownership on cross-industry acquisition's is weakened in SOEs but more prominently in non-SOEs. Compared with SOEs, nonSOEs tend to face higher trade barriers when making cross-industry acquisitions (Luo et al., 2010; Deng, 2013). However, there is a natural connection between SOEs and the government, which enables SOEs to smoothly cross the trade barriers and enter monopoly industries with considerable profits (Liang et al., 2012; Lin \& Tan, 1999). For Chinese enterprises, 
acquisition is the fastest and also most preferred way of entering a new market (Deng \& Yang, 2015). Although an acquisition often means greater resource investment, Chinese SOEs have enough resources for acquisitions, especially there are a variety of small and medium-sized enterprises (SMEs) as potential acquisition targets (Deng, 2013). SOEs with a high proportion of state-owned shares are more likely to expand to industries with high barriers of entry, and with the increase of entry degree, the economic performance of firms is significantly higher than that of other firms. In state-owned firm acquisitions, the influence of industrial state-owned proportion is not obvious, that is, the competition intensity in the industry plays a limited role (Feldman \& Kelley, 2006; Kleer, 2010). In this context, in industries with a high proportion of state-owned ownership, although SOEs would also implement cross-industry acquisitions based on policy-oriented logic, there would less significant negative impact because of their rich resources and greater risk-taking capacity (Lin \& Chou, 2016), and even if there is a loss, they may also get a certain amount of government-related resources support (Wu \& Deng, 2020). In industries with a high proportion of state-owned ownership, nonSOEs may have less stable support, and the cost of implementing cross-industry acquisition may be greater than that of SOEs (Wu \& Deng, 2020). With the higher risk of cross-industry acquisition, negative integration performance of non-SOEs will at least indirectly affect the overall development of their industry (Li \& Deng, 2017; Lin \& Chou, 2016). To summarize the above arguments, we put forward our final hypothesis as follows:

H4: The characteristics of firm ownership and industrial ownership have a moderating effect on the relationship between the acquisition type and industrial performance, that is, when the acquiring firm is state-owned, the moderating effect of the industrial state-owned ownership will decrease.

In Figure 1, we outline our conceptual framework which consists of the main variables and their relationships in the study.

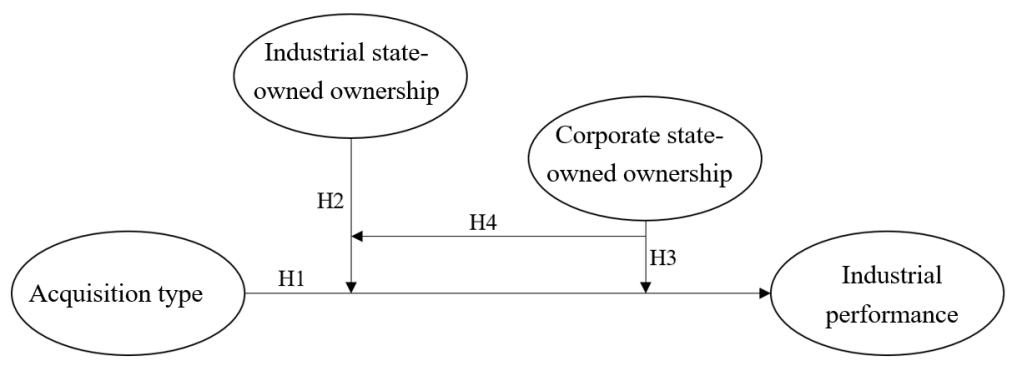

Figure 1. Relationship between acquisition type and industrial performance

\section{Methodology}

\subsection{Sample}

We select Chinese listed firms which had acquisitions from 2013 to 2016 as samples. With a rapid economic growth in China, acquisition activities of Chinese firms continue to show characteristics of high frequency, large scale, and massive quantity domestically and inter- 
nationally (Cai \& Tian, 2019; Deng \& Yang, 2015; Yue et al., 2021), which makes China as the idea research site for our research goals. The acquisition data comes from the database of Wind and GTA, the two largest data companies in China. Both WIND and GTA have established their own database of corporate acquisitions with detailed information especially on Chinese listed firms; they are widely regarded as ongoing reliable databases for academic research on listed firms in China (Lin et al., 2018; Wu \& Deng, 2020; Xin et al., 2019). Due to some mismatched information, we collect all the acquisitions in both database which have the same information. Industrial data are from the National Bureau of Statistics of China.

In addition, following prior studies (e.g., Erel et al., 2015; Cornaggia \& Li, 2019), we select the acquisitions based on the following criteria: (1) we include only the transactions that can be confirmed to have been successfully completed; (2) we delete the data of non-industrial firms and related transaction acquisition; (3) we exclude the acquisitions of only assets and the samples with missing transaction amount data.; and (4) we do not include the transactions such as special treatment (ST, which means the firm has some financial abnormity) and particular transfer (PT, which means the firm has lost in last three years) and abnormal financial data that may lead to the deviation of research results. With the above data treatment, we finally got 1,934 samples. In addition, we classify the type of acquisitions according to the following criteria. We first extract the industry category codes of the China Securities Regulatory Commission (CSRC), where all the acquiring firms are located, and then obtain the main business and specific category codes of the target firms through tianyancha.com. If the codes of both parties' main businesses are the same, we define the acquisition as an intra-industry acquisition; otherwise, as an across-industry acquisition. The final sample of this study includes 1,601 cross-industry acquisitions and 333 intra-industry acquisitions. Based on our final sample firms, we further clarify the sample classification and statistics according to the industry, ownership of acquiring firms, and acquisition time in details, which is available upon the request.

\subsection{Variables}

1. Dependent variable. In our study, the dependent variable is industrial performance (IP). We use the profit rate of the total assets of the industry to which the acquiring firm belongs one year after the acquisition event as the measurement index of industrial performance, specifically, the proportion of the total profits of the industry to the total assets. The data comes from the National Bureau of Statistics of China.

2. Independent variable. The independent variable in this study is acquisition type (AT). We divide the sample into intra- and cross-industry acquisitions based on the industries in which the two parties are located. The industry classification is in line with the classification standard of Guidelines for Industry Classification of Listed Firms issued by Securities Regulatory Commission of China in 2012. When both acquiring and target firms are in the same industry, it is treated as an intra-industry acquisition, and the value is 1; otherwise, it is a cross-industry acquisition and the value is 0 .

3. Moderating variables. There are two types of moderating variables in this study: proportion of industrial state-owned ownership (OSI) and ownership of acquiring firms (OSF). We 
measure the state-owned proportion of the industry by the proportion of state-owned shares in paid-in capital to all paid-in capital in the industry; the data comes from the National Bureau of Statistics. We measure the ownership of acquiring firms as follows: if the acquiring firm is a state-owned or controlled firm (i.e., SOE), the value is 1 ; if it is a non-state-owned or controlled firm (i.e., non-SOE), the value is 0 . The data comes from the WIND and GTA databases.

4. Control variables. Based on previous acquisition studies in the literature (e.g., Bertrand \& Capron, 2015; Cai \& Tian, 2019; Capron, 1999; Gaur et al., 2013), we control for a variety of variables, including industrial scale, acquiring firm scale (FS) and transaction scale (TS) as well as a key policy supporting industry (PS) and a cross-regional acquisition or not (RT).

In Table 1, we highlight the description and measurement of all the above variables as well as the empirical data sources.

Table 1. Description and measurement of variables

\begin{tabular}{|c|c|c|c|}
\hline Variable type & Variable name & Variable definition & Data sources \\
\hline $\begin{array}{l}\text { Dependent } \\
\text { variable }\end{array}$ & $\begin{array}{l}\text { Industrial } \\
\text { performance (IP) }\end{array}$ & $\begin{array}{l}\text { The profit rate of the total assets of the } \\
\text { industry to which the firm belongs is } \\
\text { measured by the proportion of the total } \\
\text { profits of the industry to the total assets of } \\
\text { the industry one year after the acquisition. }\end{array}$ & $\begin{array}{l}\text { National } \\
\text { Bureau of } \\
\text { Statistics }\end{array}$ \\
\hline $\begin{array}{l}\text { Independent } \\
\text { variable }\end{array}$ & $\begin{array}{l}\text { Acquisition type } \\
\text { (AT) }\end{array}$ & $\begin{array}{l}\text { Intra-industry acquisition value is } 1 \text {, cross- } \\
\text { industry acquisition value is } 0 .\end{array}$ & $\begin{array}{l}\text { WIND and } \\
\text { GTA Database }\end{array}$ \\
\hline \multirow[t]{2}{*}{$\begin{array}{l}\text { Moderating } \\
\text { variables }\end{array}$} & $\begin{array}{l}\text { State-owned } \\
\text { proportion of the } \\
\text { industry (OSI) }\end{array}$ & $\begin{array}{l}\text { The industrial state-owned proportion } \\
\text { (industrial competition intensity) is measured } \\
\text { by the proportion of industrial state-owned } \\
\text { shares in paid-in capital to all paid-in capital } \\
\text { in the industry. }\end{array}$ & $\begin{array}{l}\text { National } \\
\text { Bureau of } \\
\text { Statistics }\end{array}$ \\
\hline & $\begin{array}{l}\text { Firm ownership } \\
\text { (OSF) }\end{array}$ & $\begin{array}{l}\text { If the acquiring firm is state-owned, the value } \\
\text { is } 1 \text {, while the acquiring firm is non state- } \\
\text { owned, the value is } 0 \text {. }\end{array}$ & $\begin{array}{l}\text { WIND and } \\
\text { GTA Database }\end{array}$ \\
\hline \multirow{5}{*}{$\begin{array}{l}\text { Control } \\
\text { variables }\end{array}$} & $\begin{array}{l}\text { Acquiring firm } \\
\text { scale (FS) }\end{array}$ & $\begin{array}{l}\text { Acquiring firm scale is measured by the } \\
\text { natural logarithm of the total assets of the } \\
\text { firm in the year before the acquisition. }\end{array}$ & $\begin{array}{l}\text { WIND and } \\
\text { GTA Database }\end{array}$ \\
\hline & $\begin{array}{l}\text { Policy support } \\
\text { (PS) }\end{array}$ & $\begin{array}{l}\text { If the main business of the acquiring firm is } \\
\text { strongly supported and explicitly encouraged } \\
\text { by the CPC Central Committee's Proposal } \\
\text { on Formulating the 12th Five-Year Plan for } \\
\text { National Economic and Social Development, } \\
\text { the value is 1; otherwise, the value is } 0 \text {. }\end{array}$ & $\begin{array}{l}\text { Collected by } \\
\text { the authors }\end{array}$ \\
\hline & $\begin{array}{l}\text { Industrial scale } \\
\text { (IS) }\end{array}$ & $\begin{array}{l}\text { The industrial scale is measured by the } \\
\text { natural logarithm of the number of firms in } \\
\text { the industry. }\end{array}$ & $\begin{array}{l}\text { National } \\
\text { Bureau of } \\
\text { Statistics } \\
\end{array}$ \\
\hline & $\begin{array}{l}\text { Transaction scale } \\
\text { (TS) }\end{array}$ & $\begin{array}{l}\text { The transaction scale is measured by the } \\
\text { logarithm of the transaction amount. }\end{array}$ & $\begin{array}{l}\text { WIND and } \\
\text { GTA Database }\end{array}$ \\
\hline & Region type (RT) & $\begin{array}{l}\text { For cross-regional acquisition or not, if the } \\
\text { acquiring firm and the target firm belong to } \\
\text { different provinces, the value is } 1 \text {; otherwise, } \\
\text { the value is } 0 \text {. }\end{array}$ & $\begin{array}{l}\text { WIND and } \\
\text { GTA Database }\end{array}$ \\
\hline
\end{tabular}




\subsection{Models}

We first conduct descriptive and correlation analyses of all variables and then use the analytical method of hierarchical multiple regression to test the hypotheses if they are involved with multi-level issues (Deng \& Zhang, 2018; Meyer-Doyle et al., 2019). Our statistical testing step is as follows: We first build a regression model without acquisition type (Model 1), add the variable of acquisition type (AT) (Model 2), and compare the results of the two models to test $\mathrm{H} 1$. Then, we add the interactive item of industrial ownership and acquisition type (AT $\times$ OSI) to test H2 (Model 3) and the interactive items of firm ownership and acquisition type $(\mathrm{AT} \times \mathrm{OSF})$ to test H3 (Model 4). Finally, we construct the interaction item of ownership variables and acquisition type (AT $\times$ OSI $\times$ OSF) to test $\mathrm{H} 4$ (Model 5).

$$
\begin{aligned}
& \text { Model 1: IP }=\theta_{0}+\theta_{1} \mathrm{FS}+\theta_{2} \mathrm{PS}+\theta_{3} \mathrm{IS}+\theta_{4} \mathrm{TS}+\theta_{5} \mathrm{RT}+\varepsilon_{0} ; \\
& \text { Model 2: IP }=\alpha_{0}+\alpha_{1} \mathrm{FS}+\alpha_{2} \mathrm{PS}+\alpha_{3} \mathrm{IS}+\alpha_{4} \mathrm{TS}+\alpha_{5} \mathrm{RT}+\alpha_{6} \mathrm{AT}+\varepsilon_{1} ; \\
& \text { Model 3: IP }=\beta_{0}+\beta_{1} \mathrm{FS}+\beta_{2} \mathrm{PS}+\beta_{3} \mathrm{IS}+\beta_{4} \mathrm{TS}+\beta_{5} \mathrm{RT}+\beta_{6} \mathrm{AT}+\beta_{7} \mathrm{OSI}+\beta_{8} \mathrm{AT} \times \mathrm{OSI}+\varepsilon_{2} ; \\
& \text { Model 4: IP }=\gamma_{0}+\gamma_{1} \mathrm{FS}+\gamma_{2} \mathrm{PS}+\gamma_{3} \mathrm{IS}+\gamma_{4} \mathrm{TS}+\gamma_{5} \mathrm{RT}+\gamma_{6} \mathrm{AT}+\gamma_{7} \mathrm{OSF}+\gamma_{8} \mathrm{AT} \times \mathrm{OSF}+\varepsilon_{3} ; \\
& \text { Model 5: IP }=\delta_{0}+\delta_{1} \mathrm{FS}+\delta_{2} \mathrm{PS}+\delta_{3} \mathrm{IS}+\delta_{4} \mathrm{TS}+\delta_{5} \mathrm{RT}+\delta_{6} \mathrm{AT}+\delta_{7} \mathrm{OSI}+\delta_{8} \mathrm{OSF}+\delta_{9} \mathrm{AT} \times \\
& \text { OSI }+\delta_{10} \mathrm{AT} \times \mathrm{OSF}+\delta_{11} \mathrm{OSI} \times \mathrm{OSF}+\delta_{12} \mathrm{AT} \times \mathrm{OSI} \times \mathrm{OSF}+\varepsilon_{4} .
\end{aligned}
$$

\section{Analysis and results}

We first conduct descriptive analysis and correlation analysis of all variables. Then, we follow strategic management studies (e.g., Deng \& Zhang, 2018; Meyer-Doyle et al., 2019; Misangyi et al., 2006) and use the analytical method of hierarchical multiple regression to test the hypotheses if they are involved with multi-level issues. Our statistical hypothesis testing step is: First, we build a regression model which does not include acquisition type, then add the variable of acquisition type, and compare the results of the two models to test H1. Then, we add the interactive item of industrial ownership and acquisition type to test $\mathrm{H} 2$, and the interactive items of firm ownership and acquisition type to test H3. Finally, we construct the interaction of two ownership-related variables and acquisition type to test H4. For robustness test, we conduct additional regression analysis based on sub-samples classified by firm ownership.

\subsection{Descriptive analysis}

From the descriptive statistical analysis in Table 2, we can see that the average value of industrial performance is 7.78 , which indicates that the average return on total assets is $7.78 \%$. The average value of acquisition type is 0.23 , which indicates that $23 \%$ of the sample firms conducted intra-industry acquisitions and $77 \%$ of them acquired target firms in different industries (i.e., cross-industry acquisitions). The average value of the ownership variable of the acquiring firms is 0.18 , indicating that $18 \%$ of the samples are state-owned enterprises (SOEs), while the majority are non-SOEs. Finally, the SOE proportion of different industries averages at $12.07 \%$, but varies greatly. 
Table 2. Descriptive statistics of variables

\begin{tabular}{|l|c|c|c|c|}
\hline \multicolumn{1}{|c|}{ Variables } & Minimum value & Maximum value & Average & Standard deviation \\
\hline Industrial performance (IP) & -2.84 & 14.58 & 7.78 & 2.33 \\
\hline Acquisition type (AT) & 0.00 & 1.00 & 0.23 & 0.42 \\
\hline $\begin{array}{l}\text { State-owned proportion of } \\
\text { the industry (OSI) }\end{array}$ & 0.25 & 71.87 & 12.07 & 13.09 \\
\hline Firm ownership (OSF) & 0.00 & 1.00 & 0.18 & 0.39 \\
\hline Industrial scale (IS) & 4.95 & 10.47 & 9.39 & 0.88 \\
\hline Acquiring scale (FS) & 0.00 & 8.23 & 3.65 & 1.20 \\
\hline Transaction scale (TS) & -9.21 & 15.85 & 7.98 & 2.48 \\
\hline Region type (RT) & 0.00 & 1.00 & 0.59 & 0.49 \\
\hline Policy support (PS) & 0.00 & 1.00 & 0.50 & 0.50 \\
\hline
\end{tabular}

\subsection{Correlation analysis}

The correlation analysis among variables is listed in Table 3, indicating that there is a significant positive correlation between acquisition type and industrial performance, which to some extent supports $\mathrm{H} 1$.

Table 3. Pearson correlation coefficient matrix

\begin{tabular}{|c|c|c|c|c|c|c|c|c|}
\hline & $\begin{array}{l}\text { Industrial } \\
\text { perfor- } \\
\text { mance }\end{array}$ & $\begin{array}{l}\text { Acqui- } \\
\text { sition } \\
\text { type }\end{array}$ & $\begin{array}{l}\text { Industrial } \\
\text { state-owned } \\
\text { proportion }\end{array}$ & $\begin{array}{l}\text { Firm } \\
\text { owner- } \\
\text { ship }\end{array}$ & $\begin{array}{l}\text { Industrial } \\
\text { scale }\end{array}$ & $\begin{array}{c}\text { Acqui- } \\
\text { ring } \\
\text { scale }\end{array}$ & $\begin{array}{l}\text { Trans- } \\
\text { action } \\
\text { scale }\end{array}$ & $\begin{array}{l}\text { Area } \\
\text { type }\end{array}$ \\
\hline $\begin{array}{l}\text { Acquisition } \\
\text { type (AT) }\end{array}$ & $0.061^{\star}$ & & & & & & & \\
\hline \begin{tabular}{|l|} 
State- \\
owned pro- \\
portion of \\
the indus- \\
try (OSI)
\end{tabular} & $-0.695^{* * *}$ & 0.025 & & & & & & \\
\hline $\begin{array}{l}\text { Firm } \\
\text { ownership } \\
\text { (OSF) }\end{array}$ & $-0.170^{* * *}$ & $0.105^{\star * *}$ & $0.285^{\star * *}$ & & & & & \\
\hline $\begin{array}{l}\text { Industrial } \\
\text { scale (IS) }\end{array}$ & $0.162^{* * *}$ & 0.038 & $-0.492^{\star * *}$ & $-0.069^{* * *}$ & & & & \\
\hline $\begin{array}{l}\text { Acquiring } \\
\text { scale (FS) }\end{array}$ & $-0.137^{* * *}$ & $0.075^{\star * *}$ & $0.273^{\star * *}$ & $0.412^{* * *}$ & $-0.068^{* * *}$ & & & \\
\hline $\begin{array}{l}\text { Transaction } \\
\text { scale (TS) }\end{array}$ & -0.004 & $0.081^{\star * *}$ & 0.050 & 0.012 & $-0.070^{* * *}$ & $0.069^{* * *}$ & & \\
\hline $\begin{array}{l}\text { Region } \\
\text { type (RT) }\end{array}$ & -0.009 & 0.002 & 0.044 & $-0.061^{\star \star}$ & $-0.056^{\star \star}$ & $0.110^{* * *}$ & $0.145^{\star * *}$ & \\
\hline \begin{tabular}{|l|} 
Policy \\
support \\
(PS)
\end{tabular} & $-0.118^{\star * *}$ & 0.030 & $0.141^{\star \star \star}$ & $0.056^{\star *}$ & $-0.219^{* * *}$ & 0.019 & 0.043 & -0.050 \\
\hline
\end{tabular}

Note: ${ }^{\star} p<0.1,{ }^{* *} p<0.05$, and ${ }^{* * *} p<0.01$. 


\subsection{Regression analysis}

Table 4 shows the regression analytical results of the impact of firm acquisition type on industrial performance. In Table 4, we can see that the adjusted R square is 0.533 in the model without acquisition type while the adjusted $\mathrm{R}$ square is 0.540 in the model with acquisition type. The $\mathrm{F}$ value is significant in both models $(p<0.001)$, which indicates that acquisition type plays an important role and does have an impact on industrial performance. Most importantly, the coefficient of acquisition type is $0.479(p<0.001)$, which means that acquisition type has a significant positive effect on industrial performance, strongly supporting $\mathrm{H} 1$. That is, intra-industry acquisition has a more positive effect on industrial performance than cross-industry acquisition does.

Table 4. Regression analysis results of the impact of acquisition type on industrial performance

\begin{tabular}{|c|c|c|c|c|c|c|c|c|c|c|}
\hline \multirow[b]{2}{*}{ Variables } & \multirow[b]{2}{*}{$\begin{array}{c}\text { Coeffi- } \\
\text { cient }\end{array}$} & \multirow[b]{2}{*}{$\begin{array}{c}t \\
\text { Value }\end{array}$} & \multirow[b]{2}{*}{$\begin{array}{c}p \\
\text { Value }\end{array}$} & \multicolumn{2}{|c|}{$\begin{array}{l}\text { Collinearity } \\
\text { test }\end{array}$} & \multirow[b]{2}{*}{$\begin{array}{c}\text { Coeffi- } \\
\text { cient }\end{array}$} & \multirow[b]{2}{*}{$\begin{array}{c}t \\
\text { Value }\end{array}$} & \multirow[b]{2}{*}{$\begin{array}{c}p \\
\text { Value }\end{array}$} & \multicolumn{2}{|c|}{$\begin{array}{c}\text { Collinearity } \\
\text { test }\end{array}$} \\
\hline & & & & $\begin{array}{l}\text { Tole- } \\
\text { ran- } \\
\text { ce }\end{array}$ & $\begin{array}{l}\text { Va- } \\
\text { riance } \\
\text { ex- } \\
\text { pan- } \\
\text { sion } \\
\text { factor }\end{array}$ & & & & $\begin{array}{l}\text { Tole- } \\
\text { rance }\end{array}$ & $\begin{array}{l}\text { Va- } \\
\text { riance } \\
\text { ex- } \\
\text { pan- } \\
\text { sion } \\
\text { factor }\end{array}$ \\
\hline $\begin{array}{l}\text { Industrial } \\
\text { scale (IS) }\end{array}$ & $-0.679^{* * *}$ & -12.180 & 0.000 & 0.724 & 1.382 & $-0.695^{\star * *}$ & -12.527 & 0.000 & 0.721 & 1.386 \\
\hline $\begin{array}{l}\text { Acquiring } \\
\text { scale (FS) }\end{array}$ & $0.119^{* * *}$ & 3.028 & 0.003 & 0.784 & 1.276 & $0.114^{\star * *}$ & 2.906 & 0.004 & 0.783 & 1.277 \\
\hline $\begin{array}{l}\text { Transaction } \\
\text { scale (TS) }\end{array}$ & 0.017 & 0.982 & 0.326 & 0.971 & 1.030 & 0.01 & 0.605 & 0.545 & 0.965 & 1.036 \\
\hline $\begin{array}{l}\text { Region } \\
\text { type (RT) }\end{array}$ & 0.016 & 0.181 & 0.856 & 0.950 & 1.053 & 0.017 & 0.196 & 0.844 & 0.95 & 1.053 \\
\hline $\begin{array}{l}\text { Policy sup- } \\
\text { port (PS) }\end{array}$ & $-0.279^{\star * *}$ & -3.243 & 0.001 & 0.945 & 1.059 & $-0.293^{* * *}$ & -3.423 & 0.001 & 0.944 & 1.06 \\
\hline $\begin{array}{l}\text { State- } \\
\text { owned } \\
\text { propor- } \\
\text { tion of the } \\
\text { industry } \\
\text { (OSI) }\end{array}$ & $-0.149^{\star * *}$ & -38.277 & 0.000 & 0.671 & 1.490 & $-0.15^{* * *}$ & -38.627 & 0.000 & 0.671 & 1.491 \\
\hline $\begin{array}{l}\text { Firm } \\
\text { ownership } \\
\text { (OSF) }\end{array}$ & 0.178 & 1.463 & 0.144 & 0.783 & 1.277 & 0.132 & 1.091 & 0.275 & 0.778 & 1.285 \\
\hline $\begin{array}{l}\text { Acquisition } \\
\text { type (AT) }\end{array}$ & & & & & & $0.479^{* * *}$ & 4.799 & 0.000 & 0.978 & 1.023 \\
\hline $\mathrm{R}^{2}$ & \multicolumn{5}{|c|}{0.535} & \multicolumn{5}{|c|}{0.543} \\
\hline Adj- $R^{2}$ & \multicolumn{5}{|c|}{0.533} & \multicolumn{5}{|c|}{0.540} \\
\hline $\mathrm{F}$ & \multicolumn{5}{|c|}{$236.98^{\star * *}$} & \multicolumn{5}{|c|}{$213.412^{* * *}$} \\
\hline
\end{tabular}

Note: ${ }^{\star} p<0.1,{ }^{* *} p<0.05$, and ${ }^{* *} p<0.01$. This table shows the regression results of Models 1 and 2. 
In Table 4, we can also see that the coefficient of industrial state-owned proportion is significantly negative $(p<0.001)$, indicating that the industrial state-owned proportion has a negative impact on industrial performance. Moreover, the industrial scale and policy support both show significant negative correlation $(p<0.001)$, while the acquiring firm scale shows significant positive correlation $(p<0.001)$, while the transaction scale and area type show no correlation.

Table 5 shows the regression analysis results of the moderating effect of industrial ownership characteristics. As the coefficient of the interaction between acquisition type and industrial ownership characteristics is $0.05(p<0.001)$, there is a significant moderating effect and $\mathrm{H} 2$ is verified. That is, when the proportion of industrial state-owned is high, intra-industry acquisition will play a stronger positive role in industrial performance. Based on the regression results, we drew a schematic diagram of moderating effect. As shown in Figure 2, when the proportion of state-owned shares is higher, the slope of the linear function formed by the acquisition type and industrial performance is becoming larger, indicating that the industrial state-owned proportion has an obvious moderating effect.

Table 5. The moderating effect of industrial state-owned proportion

\begin{tabular}{|c|c|c|c|c|c|}
\hline \multirow[b]{2}{*}{ Variables } & \multirow[b]{2}{*}{ Coefficient } & \multirow[b]{2}{*}{$t$ Value } & \multirow[b]{2}{*}{$p$ Value } & \multicolumn{2}{|c|}{ Collinearity test } \\
\hline & & & & Tolerance & $\begin{array}{l}\text { Variance } \\
\text { expansion } \\
\text { factor }\end{array}$ \\
\hline Industrial scale (IS) & $-0.776^{\star * \star}$ & -13.957 & 0.000 & 0.692 & 1.445 \\
\hline Acquiring scale (FS) & $0.108^{\star *}$ & 2.825 & 0.005 & 0.783 & 1.277 \\
\hline Transaction scale (TS) & 0.013 & 0.793 & 0.428 & 0.964 & 1.037 \\
\hline Region type (RT) & 0.004 & 0.051 & 0.959 & 0.949 & 1.053 \\
\hline Policy support (PS) & $-0.333^{* * *}$ & -3.96 & 0.000 & 0.939 & 1.065 \\
\hline Firm ownership (OSF) & 0.114 & 0.954 & 0.34 & 0.778 & 1.286 \\
\hline $\begin{array}{l}\text { State-owned proportion } \\
\text { of the industry (OSI) }\end{array}$ & $-0.167^{\star * \star}$ & -37.007 & 0.000 & 0.475 & 2.107 \\
\hline Acquisition type (AT) & $0.472^{* * *}$ & 4.813 & 0.000 & 0.978 & 1.023 \\
\hline $\begin{array}{l}\text { Acquisition type and } \\
\text { State-owned proportion } \\
\text { of the industry (AT }{ }^{*} \\
\text { OSI) }\end{array}$ & $0.05^{* * *}$ & 7.276 & 0.000 & 0.657 & 1.521 \\
\hline $\mathrm{R}^{2}$ & \multicolumn{5}{|c|}{0.559} \\
\hline Adj- $R^{2}$ & \multicolumn{5}{|c|}{0.556} \\
\hline $\mathrm{F}$ & \multicolumn{5}{|c|}{$202.433^{* * *}$} \\
\hline
\end{tabular}

Note: ${ }^{*} p<0.1,{ }^{* *} p<0.05$, and ${ }^{* *} p<0.01$. This table shows the regression results of Model 3.

The moderating effects of firm ownership characteristics are shown in Table 6, where the regression coefficient of the interaction item between the acquisition type and the firm ownership characteristic is 0.416 . The test on the significance level of $p<0.1$ shows that the firm ownership characteristic also has a significant moderating effect on the acquisition type 


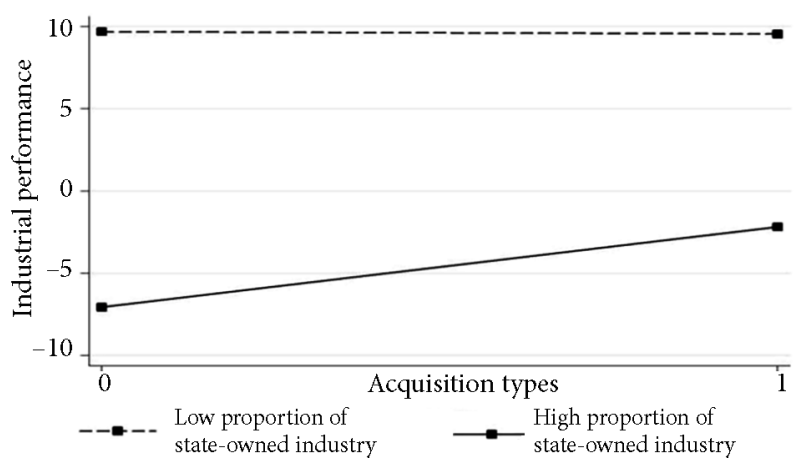

Figure 2. Moderating role of industrial state-owned proportion

and the industrial performance. Based on the regression results, we also drew a schematic diagram of the moderating effect of firm ownership. As shown in Figure 3, the slope of the linear function formed by the acquisition type and industrial performance is becoming larger in state-owned firm acquisition, which indicates that the firm's ownership has an obvious moderating effect, thus verifying $\mathrm{H} 3$.

Table 6. The moderating effect of firm ownership characteristics

\begin{tabular}{|c|c|c|c|c|c|}
\hline \multirow[b]{2}{*}{ Variables } & \multirow[b]{2}{*}{ Coefficient } & \multirow[b]{2}{*}{$t$ Value } & \multirow[b]{2}{*}{$p$ Value } & \multicolumn{2}{|c|}{ Collinearity test } \\
\hline & & & & Tolerance & $\begin{array}{l}\text { Variance } \\
\text { expansion } \\
\text { factor }\end{array}$ \\
\hline Industrial scale (IS) & $-0.701^{* * *}$ & -12.625 & 0.000 & 0.718 & 1.392 \\
\hline Acquiring scale (FS) & $0.111^{\star *}$ & 2.838 & 0.005 & 0.782 & 1.279 \\
\hline Transaction scale (TS) & 0.011 & 0.66 & 0.51 & 0.964 & 1.037 \\
\hline Region type(RT) & 0.01 & 0.11 & 0.913 & 0.947 & 1.055 \\
\hline Policy support (PS) & $-0.29^{\star *}$ & -3.391 & 0.001 & 0.943 & 1.06 \\
\hline $\begin{array}{l}\text { State-owned proportion of the } \\
\text { industry (OSI) }\end{array}$ & $-0.15^{\star * *}$ & -38.677 & 0.000 & 0.667 & 1.499 \\
\hline Firm ownership (OSF) & 0.016 & 0.113 & 0.91 & 0.598 & 1.672 \\
\hline Acquisition type (AT) & $0.384^{\star *}$ & 3.374 & 0.001 & 0.753 & 1.327 \\
\hline $\begin{array}{l}\text { Acquisition type and Firm } \\
\text { ownership }(\mathrm{AT} \times \mathrm{OSF})\end{array}$ & $0.416^{*}$ & 1.755 & 0.079 & 0.547 & 1.829 \\
\hline $\mathrm{R}^{2}$ & \multicolumn{5}{|c|}{0.544} \\
\hline Adj-R ${ }^{2}$ & \multicolumn{5}{|c|}{0.541} \\
\hline $\mathrm{F}$ & \multicolumn{5}{|c|}{$190.316^{* * *}$} \\
\hline
\end{tabular}

Note: ${ }^{\star} p<0.1,{ }^{* *} p<0.05$, and ${ }^{* * *} p<0.01$. This table shows the regression results of Model 4 .

Table 7 shows the regression results testing H4, indicating the empirical analysis on the moderating effect of the state-owned proportion and firm ownership. Based on Table 7, the joint interaction items of acquisition type, industrial ownership characteristics and firm 


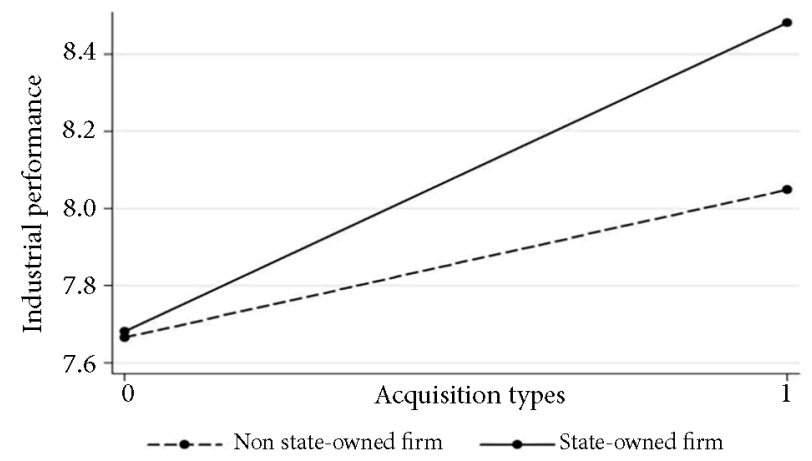

Figure 3. Moderating role of firm ownership

ownership characteristics have a regression coefficient of $-0.036(p<0.05)$, indicating that the moderating effect of firm ownership characteristics on industrial ownership characteristics has a negative impact. That is, in the acquisitions made by SOEs, the moderating effect of industrial ownership characteristics on the relationship between acquisition type and acquisition performance will be reduced. To show this moderating effect more intuitively, we drew an interactive effect diagram of the results. As shown in Figure 4. under the moderating effect of the firm ownership, the moderating effect of the SOE proportion changes further, mainly in industries with a high state-owned proportion. The positive effect of non-SOE acquisition on industrial performance is higher than that of SOE acquisition on industrial performance, supporting $\mathrm{H} 4$.

Table 7. The moderating effect of industrial state-owned proportion and firm ownership

\begin{tabular}{|l|c|c|c|c|c|}
\hline \multirow{2}{*}{ Variable } & \multirow{2}{*}{ Coefficient } & \multirow{2}{*}{$t$ Value } & \multirow{2}{*}{$p$ Value } & \multicolumn{2}{c|}{ Collinearity test } \\
\cline { 5 - 6 } & & & & Tolerance & $\begin{array}{c}\text { Variance } \\
\text { expansion factor }\end{array}$ \\
\hline Industrial scale (IS) & $-0.957^{* * *}$ & -17.464 & 0.000 & 0.643 & 1.555 \\
\hline Acquiring scale (FS) & $0.072^{*}$ & 1.958 & 0.05 & 0.775 & 1.29 \\
\hline Transaction scale (TS) & 0.014 & 0.855 & 0.393 & 0.963 & 1.038 \\
\hline Region types (RT) & -0.011 & -0.137 & 0.891 & 0.947 & 1.056 \\
\hline Policy support (PS) & $-0.496^{* * *}$ & -6.116 & 0.000 & 0.914 & 1.094 \\
\hline $\begin{array}{l}\text { State-owned proportion of the } \\
\text { industry (OSI) }\end{array}$ & $-0.214^{* * *}$ & -36.893 & 0.000 & 0.262 & 3.822 \\
\hline Firm ownership (OSF) & -0.08 & -0.608 & 0.543 & 0.571 & 1.751 \\
\hline Acquisition type (AT) & $0.488^{* * *}$ & 4.449 & 0.000 & 0.705 & 1.419 \\
\hline $\begin{array}{l}\text { Acquisition type and State-owned } \\
\text { proportion of the industry (AT } \times \\
\text { OSI) }\end{array}$ & $0.057^{* * *}$ & 4.957 & 0.000 & 0.212 & 4.726 \\
\hline $\begin{array}{l}\text { Acquisition type and Firm } \\
\text { ownership (AT } \times \text { OSF) }\end{array}$ & 0.093 & 0.394 & 0.694 & 0.483 & 2.069 \\
\hline
\end{tabular}


End of Table 7

\begin{tabular}{|c|c|c|c|c|c|}
\hline \multirow[b]{2}{*}{ Variable } & \multirow[b]{2}{*}{ Coefficient } & \multirow[b]{2}{*}{$t$ Value } & \multirow[b]{2}{*}{$p$ Value } & \multicolumn{2}{|c|}{ Collinearity test } \\
\hline & & & & Tolerance & $\begin{array}{c}\text { Variance } \\
\text { expansion factor }\end{array}$ \\
\hline $\begin{array}{l}\text { State-owned proportion of the } \\
\text { industry and Firm ownership } \\
(\text { OSI } \times \text { OSF) }\end{array}$ & $0.092^{\star * *}$ & 11.878 & 0.000 & 0.279 & 3.579 \\
\hline $\begin{array}{l}\text { Acquisition type and state-owned } \\
\text { proportion of the industry and firm } \\
\text { ownership (AT } \times \text { OSI } \times \text { OSF) }\end{array}$ & $-0.036^{\star}$ & -2.512 & 0.012 & 0.19 & 5.269 \\
\hline $\mathrm{R}^{2}$ & \multicolumn{5}{|c|}{0.603} \\
\hline Adj-R ${ }^{2}$ & \multicolumn{5}{|c|}{0.600} \\
\hline $\mathrm{F}$ & \multicolumn{5}{|c|}{$181.622^{* * *}$} \\
\hline
\end{tabular}

Note: ${ }^{\star} p<0.1,{ }^{* *} p<0.05$, and ${ }^{* * *} p<0.01$. This table shows the regression results of Model 5.

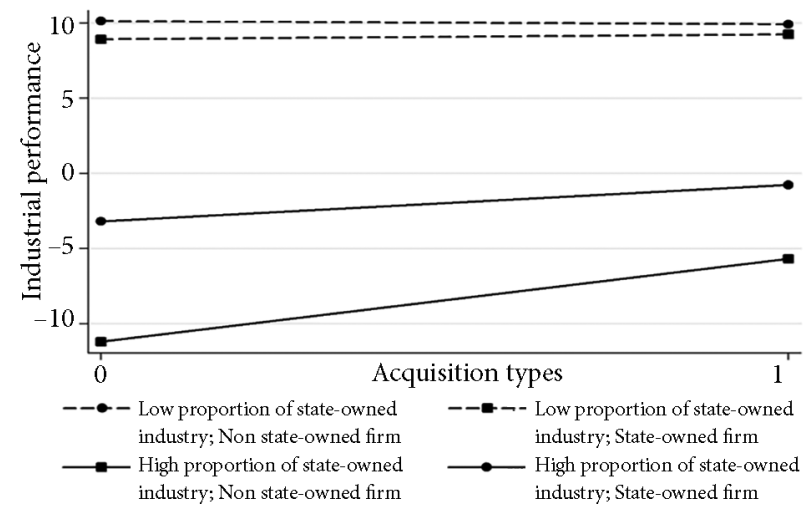

Figure 4. Joint moderation of industrial state-owned proportion and firm ownership

Further, for robustness test, we classified the sample based on firm ownership and made regression analysis of moderating effect of moderating effect of industrial ownership with sub-samples of both SOEs and non-SOEs. As the coefficient of the interaction item of acquisition type and industrial ownership in both sub samples are significantly positive, the moderating effect of industrial ownership does exist. The coefficient in SOE sample is significantly smaller than in non-SOE sample, which indicates the moderating effect of industrial ownership would be lower when the acquisitions are conducted by SOEs, supporting H4 again.

\section{Discussion}

Based on the dataset of 1,934 acquisitions of listed firms in China from 2013 to 2016, this study focuses on the impact of firm acquisition type on industrial performance and analyzes the moderating effect of industrial ownership characteristic and firm ownership attributes on the relationship between them from the perspective of ownership theory. The major findings are highlighted as follows. 
First, different industrial types of acquisitions have significantly different influence on industrial performance in China. Intra-industry acquisition tends to have positive effect on industrial performance, while cross-industry acquisition has less positive and even negative effect. Although prior studies (e.g., Jo \& Kim, 2019) support the positive effect of crossindustry acquisition on enterprises, our study further proves the positive effect by finding that the positive impact of intra-industry acquisition on macro-level, industrial performance is higher than that of cross-industry acquisition. On the one hand, it is because of the scale effect and synergy effect of peer acquisition on enterprises. On the other hand, it is more important for emerging markets that peer acquisition reduces the vicious competition in the industry, improves the competitiveness of enterprises, and optimizes the industrial structure (Gaur et al., 2013; Sears \& Hoetker, 2014). While cross-industry acquisition might bring some benefits to the acquiring firm, it would be less positive for the whole industry than intra-industry acquisition because of less resources focusing on main businesses and more diversification-trap risk in emerging market.

Second, corporate ownership and industrial ownership attributes exert moderating effect on the relationship between acquisition type and industrial performance. For the moderating effect of industrial ownership, we find that the higher the proportion of SOEs in the industry, the more significant the positive effect of firms' intra-industry acquisition on industrial performance. This is consistent with the arguments of institutional theory and market structure view that the state-owned ownership in industry have significant effect on both industrial competition structure and corporate behavior (Cai \& Tian, 2019; Deng, 2013; Yue et al., 2021). For the moderating effect of the acquirer's ownership, we find that, compared with non-SOEs, intra-industry acquisitions of SOEs has a higher significant positive effect on industrial performance. This finding proves that Chinese SOEs may have more resources and institutional advantages which could influence the industrial structure.

Third, regarding the joint moderating effect of industrial ownership and corporate ownership, we find that corporate state-owned ownership weakens the moderating effect of industrial effect. Specifically, when the acquiring firm is state-owned, the moderating effect of the proportion of state-owned industry on the relationship between acquisition type and industrial performance would be lower. This finding indicates that corporate capability and especially institutional advantage may have more influences than external environment in China (Luo et al., 2010; Wu \& Deng, 2020). As both firm-level ownership and industrylevel ownership characteristics have an impact on the macro-level industrial performance, our study confirms that the institutional environment and institutional factors in emerging countries continue to play a vital role in corporate behaviors and industrial development (Deng et al., 2020; Peng et al., 2008).

Our conceptual arguments and empirical findings have contributed to the relevant literatures in three distinct ways. First, this study enriches the research of macro-level effect of corporate acquisitions in emerging markets. By analyzing the impact of corporate acquisition type on industrial performance, we enrich the study of the relationship between the micro-level firm acquisition behaviors and the macro-level industrial development. Given that the existing research explains mainly the role of firm acquisitions from the micro level (Tehseen et al., 2021), our work enriches the studies on firm acquisition behaviors especially 
on different types of acquisitions (Deng \& Yang, 2015; Yue et al., 2021). In so doing, our study also integrates the potential barriers between micro and macro research of industries to a certain extent.

Second, we enrich the relevant studies on the influencing factors of industrial performance in emerging markets. We find that different acquisition types have significantly different effect on industrial performance and such effect would be varied in the different condition of industrial ownership structure and corporate ownership characteristics. In the existing studies on the antecedents of industrial performance, although several studies did consider individual-level or organization-level factors, the majority of existing studies focused on macro-level factors (Blonigen, 2016). A value-added contribution of our study lies in explicitly clarifying that the research of micro-level factors can influence industrial performance from the perspective of firm acquisitions across both intra-industry and cross-industry dimensions.

Third, our study enriches the research of the corporate strategic behavior and industrial development of emerging markets from the ownership view and institutional theory. Institutional theory is regarded as an effective perspective to explain the behavior of enterprises in emerging markets (Deng, 2013; Peng et al., 2008). This study further reveals that enterprise ownership and industrial ownership structure have a significant impact on the institutional environment in which the enterprise is located, and then on corporate decision and performance, as well as on industrial structure and performance.

This study has also generated managerial and policy implications. For business managers, it is important to grasp the impact of different types of acquisitions on industrial performance under diverse conditions. Understanding such differential impacts could provide certain decision-making basis for firms to choose more effective acquisition methods in different industries and also make better use of firm acquisition activities to promote the optimization of industrial structure and thus improve the firm's competitive advantage. For policy makers, our study may provide some useful information and reference particularly in terms of clarifying the differences in the impact of intra-industry acquisitions and crossindustry acquisitions on industrial performance and their changes associated with different characteristics of firms and industries. Equipped with such information, government officials could be better prepared to formulate pertinent industrial policies, further improving the policy efficiency of industrial restructuring and transformation and upgrading.

Our study has some limitations which may provide promising research opportunities in the future. First, the acquisitions were conducted by listed firms in China. However, nonlisted Chinese firms and their impact on the industrial development should not be underestimated (Chen et al., 2017; Deng \& Zhang, 2018; Tehseen et al., 2021). In the future, researchers need further explore those non-listed Chinese firms and their acquisition endeavors by using other databases. Second, based on the existing studies, we measured the industrial data one year behind. However, the impact of corporate activities on the industry could take a longer time to take effect (Cai \& Tian, 2019). To achieve more in-depth analytical results, future studies may take the industrial performance measurement with the lag of 2-3 years. Third, although we have taken into account a variety of control variables, there may be more related factors that could influence acquisitions and industrial performance. Future studies may consider other control variables and further explore the moderating effect. 


\section{Conclusions}

Based on a dataset of 1,934 acquisitions of listed firms in China, we examined the relationship between corporate acquisition type and industrial performance. Major findings indicate that intra-industry acquisitions have a stronger positive effect on industrial performance than cross-industry acquisitions and ownership variables exert different and also joint moderating effects on the relationship between acquisition type and industrial performance.

By empirically investigating how multi-level factors influence industrial performance, the research enriches the ownership theory and institutional theory on the acquisition behaviours of firms and industrial performance in the context of emerging markets. In addition, we have also generated implications for business practitioners so that they could better leverage different types of acquisition activities to promote their industrial positions. For policy makers, these findings may enable them to enhance the policy efficiency of industrial transformation and structural upgrade. In sum, by proposing a model of how corporate acquisition influences industrial performance, this study enriched an understanding of the relationship between firm acquisition and industrial development, thereby integrating the potential barriers between micro- and macro-level research of industries.

\section{Acknowledgements}

We thank Managing Editor, Dr. Martinkutė Kaulienè and two anonymous reviewers for their constructive comments and guidance. The first author, Dr. Qi Yue, acknowledges the support from the National Social Science Foundation of China (Grant \#18BGL024). The research was in part accomplished when Dr. Qi Yue was a visiting scholar under the supervision of the second author in the Monte Ahuja College of Business at Cleveland State University, Ohio, USA, August 2019-August 2020. Dr. Ping Deng acknowledges support of the Monte Ahuja Endowment Fund for the Chair of Global Business at Cleveland State University; he is the corresponding author of this article.

\section{Funding}

This research was supported by the National Social Science Foundation of China under Grant \# 18BGL024.

\section{Disclosure statement}

The authors declare no conflicts of financial, professional, or personal interests from other parties.

\section{References}

Ahn, S., Denis, D. J., \& Denis, D. K. (2006). Leverage and investment in diversified firms. Journal of Financial Economics, 79(2), 317-337. https://doi.org/10.1016/j.jineco.2005.03.002 
Bergh, D. (1997). Predicting divestiture of unrelated acquisitions: An integrative model of exante conditions. Strategic Management Journal, 18(9), 715-731.

https://doi.org/10.1002/(SICI)1097-0266(199710)18:9<715::AID-SMJ912>3.0.CO;2-6

Bertrand, O., \& Capron, L. (2015). Productivity enhancement at home via cross-border acquisitions. Strategic Management Journal, 36(5), 640-658. https://doi.org/10.1002/smj.2256

Bettinazzi, E. M., \& Zollo, M. (2017). Stakeholder orientation and acquisition performance. Strategic Management Journal, 38(12), 2465-2485. https://doi.org/10.1002/smj.2672

Blonigen, B. A. (2016). Industrial policy and downstream export performance. Economic Journal, 126(595), 1635-1659. https://doi.org/10.1111/ecoj.12223

Brito, D. (2003). Preemptive mergers under spatial competition. International Journal of Industrial Organization, 21(10), 1601-1622. https://doi.org/10.1016/S0167-7187(03)00048-1

Cai, Q. F., \& Tian, L. (2019). Industrial policy and cross-industrial M\&As. Chinese Industrial Economics, 36(1), 81-99.

Capron, L. (1999). The long-term performance of horizontal acquisitions. Strategic Management Journal, 20(11), 987-1018.

https://doi.org/10.1002/(SICI)1097-0266(199911)20:11<987::AID-SMJ61>3.0.CO;2-B

Capron, L., \& Pistre, N. (2002). When do acquirers earn abnormal returns? Strategic Management Journal, 23(9), 781-794. https://doi.org/10.1002/smj.262

Chakrabarti, A., \& Mitchell, W. (2016). The role of geographic distance in completing related acquisitions. Strategic Management Journal, 37(4), 673-694. https://doi.org/10.1002/smj.2366

Chen, F. (2008). The Motives for international acquisitions. Journal of International Business Studies, 39(3), 454-471. https://doi.org/10.1057/palgrave.jibs.8400357

Chen, F., Li, F., \& Meng, Q. (2017). Integration and autonomy in Chinese technology-sourcing crossborder M\&As. Technology Analysis \& Strategic Management, 29(9), 1002-1014. https://doi.org/10.1080/09537325.2016.1261102

Cornaggia, J., \& Li, J. Y. (2019). The value of access to finance: Evidence from M\&As. Journal of Financial Economics, 131(1), 232-250. https://doi.org/10.1016/j.jfineco.2018.09.003

Cuypers, I. R. P., Cuypers, Y., \& Martin, X. (2017). When the target may know better. Strategic Management Journal, 38(3), 609-625. https://doi.org/10.1002/smj.2502

Deng, P. (2013). Chinese outward direct investment research: Theoretical integration and recommendations. Management and Organization Review, 9(3), 513-539. https://doi.org/10.1111/more.12030

Deng, P., \& Yang, M. (2015). Cross-border mergers and acquisitions by emerging market firms: A comparative investigation. International Business Review, 24(1), 157-172. https://doi.org/10.1016/j.ibusrev.2014.07.005

Deng, P., \& Zhang, S. (2018). Institutional quality and internationalization of emerging market firms. Journal of Business Research, 92, 279-289. https://doi.org/10.1016/j.jbusres.2018.07.014

Deng, P., Delios, A., \& Peng, M. (2020). A geographic relational perspective on the internationalization of emerging market firms. Journal of International Business Studies, 51(1), 50-71. https://doi.org/10.1057/s41267-019-00276-y

Erel, I., Jang, Y., \& Weisbach, M. S. (2015). Do acquisitions relieve target firms' financial constraints? Journal of Finance, 70(1), 289-328. https://doi.org/10.1111/jofi.12155

Feldman, M. P., \& Kelley, R. (2006). The ex ante assessment of knowledge spillovers. Research Policy, 35(10), 1509-1521. https://doi.org/10.1016/j.respol.2006.09.019

Furfine, C. H., \& Rosen, R. J. (2011). Mergers increase default risk. Journal of Corporate Finance, 17(4), 832-849. https://doi.org/10.1016/j.jcorpfin.2011.03.003

Garcia-Castro, R., \& Francoeur, C. (2016). When more is not better. Strategic Management Journal, 37(2), 406-424. https://doi.org/10.1002/smj.2341 
Gaur, A. S., Malhotra, S., \& Zhu, P. (2013). Acquisition announcements and stock market valuations of acquiring firms' rivals. Strategic Management Journal, 34(2), 215-232. https://doi.org/10.1002/smj.2009

Graebner, M., Heimeriks, K., Huy, Q., Vaara, E., Sonenshein, S., \& Boje, D. (2017). The process of postmerger integration. Academy of Management Annals, 11(1), 1-32. https://doi.org/10.5465/annals.2014.0078

Harris, R. S., \& Ravenscraft, D. (1991). The role of acquisitions in foreign direct investment: Evidence from the U.S. stock market. Journal of Finance, 46(3), 825-844. https://doi.org/10.1111/j.1540-6261.1991.tb03767.x

Hitt, M. A., Hoskisson, R., Johnson, A., \& Moesel, D. (1996). The market for corporate control and firm innovation. Academy of Management Journal, 39(5), 1084-1119.

Humphery-Jenner, M., Sautner, Z., \& Suchard, J. (2017). Cross-border mergers and acquisitions: The role of private equity firms. Strategic Management Journal, 38(8), 1688-1700. https://doi.org/10.1002/smj.2623

Jo, Y., \& Kim, J. (2019). The impact of experience on private target acquisition in high-technology industries. Sustainability, 11(6), 1603. https://doi.org/10.3390/su11061603

Jovanovic, B., \& Braguinsky, S. (2004). Bidder discounts and target premium in takeovers. American Economic Review, 94(1), 46-56. https://doi.org/10.1257/000282804322970698

Karim, S. (2006). Modularity in organizational structure. Strategic Management Journal, 27(9), 799-823. https://doi.org/10.1002/smj.547

King, D. R., Dalton, D. R., Daily, C. M., \& Covin, J. G. (2004). Meta-analyses of post-acquisition performance. Strategic Management Journal, 25(2), 187-200. https://doi.org/10.1002/smj.371

Kleer, R. (2010). Government R\&D subsidies as a signal for private investors. Research Policy, 39(10), 1361-1374. https://doi.org/10.1016/j.respol.2010.08.001

Li, J., \& Wan, G. (2016). China's cross-border mergers and acquisitions: A contextual distance perspective. Management and Organization Review, 12(3), 449-456. https://doi.org/10.1017/mor.2016.23

Li, J., Li, P., \& Wang, B. (2019). The liability of opaqueness: State ownership and the likelihood of deal completion. Strategic Management Journal, 40(2), 303-327. https://doi.org/10.1002/smj.2985

Li, Q., \& Deng, P. (2017). From international new ventures to MNCs: Cross the chasm effect on internationalization paths. Journal of Business Research, 70(1), 92-100. https://doi.org/10.1016/j.jbusres.2016.07.002

Liang, X., Lu, X., \& Wang, L. (2012). Outward internationalization of private enterprises in China. Journal of World Business, 47(1), 134-144. https://doi.org/10.1016/j.jwb.2011.02.002

Lin, H.-C., \& Chou, Y.-Y. (2016). The Impact of industry commonality on post-merger performance. Advances in Economics and Business, 46(6), 297-305. https://doi.org/10.13189/aeb.2016.040604

Lin, J. Y., \& Tan, G. (1999). Policy burdens, accountability, and the soft budget constraint. American Economic Review, 89(2), 426-431. https://doi.org/10.1257/aer.89.2.426

Lin, S. L., Lu, J., Su, J.-B., \& Chen, W.-P. (2018). Sustainable returns: The effect of regional industrial development policy. Sustainability, 10(8), 2769. https://doi.org/10.3390/su10082769

Lins, K. V., \& Servaes, H. (2002). Is corporate diversification beneficial in emerging markets? Financial Management, 31(2), 5-31.

Louis, M. R. (1980). Surprise and sense making: What newcomers experience in entering unfamiliar organizational settings. Administrative Science Quarterly, 25(2), 226-251. https://doi.org/10.2307/2392453

Luo, Y., Xue, Q., \& Han, B. (2010). How emerging market governments promote outward FDI: Experience from China. Journal of World Business, 45(1), 68-79. https://doi.org/10.1016/j.jwb.2009.04.003 
Makri, M., Hitt, M. A., \& Lane, P. J. (2010). Complementary technologies, knowledge relatedness, and invention outcomes in high technology mergers and acquisitions. Strategic Management Journal, 31(6), 602-628. https://doi.org/10.1002/smj.829

Marcela, M., DiVito, L., \& Desyllas, P. (2016). When do acquirers invest in the R\&D assets of acquired science-based firms in cross-border acquisitions? Long Range Planning, 49(2), 221-240. https://doi.org/10.1016/j.lrp.2015.07.002

Meuer, J. (2014). Archetypes of inter-firm relations in the implementation of management innovation. Organization Studies, 35(1), 121-145. https://doi.org/10.1177/0170840613495339

Meyer-Doyle, P., Lee, S., \& Helfat, C. (2019). Disentangling the microfoundations of acquisition behavior and performance. Strategic Management Journal, 40(11), 1733-1756. https://doi.org/10.1002/smj.3069

Misangyi, V. F., Elms, H., Greckhamer, T., \& Lepine, J. A. (2006). A new perspective on a fundamental debate. Strategic Management Journal, 27(6), 571-590. https://doi.org/10.1002/smj.530

Orsi, L., Ganzaroli, A., De Noni, I., \& Marelli, F. (2015). Knowledge utilisation drivers in technological M\&As. Technology Analysis \& Strategic Management, 27(8), 877-894. https://doi.org/10.1080/09537325.2015.1023788

Palich, L., Cardinal, B., \& Miller, C. (2000). Curvilinearity in the diversification-performance linkage. Strategic Management Journal, 21(2), 155-174. https://doi.org/10.1002/(SICI)1097-0266(200002)21:2

Park, C. (2003). Prior performance characteristics of related and unrelated acquirers. Strategic Management Journal, 24(5), 471-480. https://doi.org/10.1002/smj.310

Peng, M. W., Wang, D., \& Jiang, Y. (2008). An institution-based view of international business strategy. Journal of International Business Studies, 39(5), 920-936. https://doi.org/10.1057/palgrave.jibs.8400377

Sears, J., \& Hoetker, G. (2014). Technological overlap, technological capabilities, and resource recombination in technological acquisitions. Strategic Management Journal, 35(1), 48-67. https://doi.org/10.1002/smj.2083

Tan, Q., \& Sousa, M. (2018). Performance and business relatedness as drivers of exit decision: A study of MNCs from an emerging country. Global Strategy Journal, 8(4), 612-634. https://doi.org/10.1002/gsj.1170

Tehseen, S., Deng, P., Wu, B., \& Gao, Y. (2021). Culture values and entrepreneurial innovations: A comparative study of Malaysian ethnic entrepreneurs. Journal of Small Business Management, ahead-ofprint. https://doi.org/10.1080/00472778.2021.1934848

Tian, M., Deng, P., Zhang, Y., \& Salmador, M. P. (2018). How does culture influence innovation? A systematic literature review. Management Decision, 56(5), 1088-1107. https://doi.org/10.1108/MD-05-2017-0462

Vega Martinez, E., Martinez Serna, M., \& Parga Montoya, N. (2020). Dimensions of learning and its impact on organizational performance and competitiveness in SMEs. Journal of Business Economics and Management, 21(2), 395-420. https://doi.org/10.3846/jbem.2020.11801

Wu, B., \& Deng, P. (2020). Internationalization of SMEs from emerging markets: An institutional escape perspective. Journal of Business Research, 108, 337-350. https://doi.org/10.1016/j.jbusres.2019.10.037

Xin, K., Sun, Y., Zhang, R., \& Liu, X. (2019). Debt financing and technology innovation: Evidence from China. Journal of Business Economics and Management, 20(5), 841-859. https://doi.org/10.3846/jbem.2019.10185

Yan, H., Wang, J., \& Deng, P. (2018). Outbound linkage and inbound leverage for emerging multinationals: A signaling theory perspective. Asia Pacific Journal of Management, 35(2), 347-372. https://doi.org/10.1007/s10490-017-9554-8 
Yin, X., \& Shanley, M. (2008). Industry determinants of the "merger versus alliance" decision. Academy of Management Review, 33(2), 473-491. https://doi.org/10.5465/AMR.2008.31193515

Yue, Q., Deng, P., Cao, Y., \& Hua, X. (2021). Post-acquisition control strategy and cross-border acquisition performance of Chinese MNEs: A fsQCA approach. Management Decision, 59(12), 2970-2991. https://doi.org/10.1108/MD-08-2020-0986

Zaremba, A., Szyszka, A., Plotnicki, M., \& Grobelny, P. (2018). Post-merger returns in frontier markets, or how we learned to stop worrying and love the acquirers. Journal of Business Economics and Management, 19(1), 96-109. https://doi.org/10.3846/16111699.2017.1399162 